\title{
TILbAGEFøRING AF KULTURGODS MELLEM DANMARK OG TYSKLAND
}

\author{
Inge Adriansen
}

I 2003 vil Nationalmuseet i København vise en stor udstilling med Nydambåden, et af de mest opsigtsvakkende danske mosefund. Den originale båd anses for kulturarv både $i$ Slesvig-Holsten og i Danmark, og den bliver udlant af Schleswig-Holsteinisches Landesmuseum på Schloss Gottorf i Schleswig under den stiltiende forudsatning, at båden kan vende tilbage til den del af Slesvig, der er tysk, uden at der på ny rejses officielle udleveringskrav fra dansk side. Der er nappe tvivl om, at disse krav vil blive respekteret fra officiel side, men der er nappe heller tvivl om, at der fra uofficiel side vil komme krav om, at Nydambåden skal forblive i Danmark som umistelig kulturarv. For i mere end 100 àr har Nydambåden veret en af de museumsgenstande, hvorom der var størst dansk-tysk uenighed.

Men hvordan kan en stor tung robåd, der er dateret til germansk jernalder 3-400 år før grundlæggelsen af Det Danske Rige, fortolkes som dansknationalt kulturgods? Hvad er det for egenskaber, der bevirker, at visse museumsgenstande tillægges en betydning som umisteligt kulturgods og andre ikke gør det? Dette vil jeg forsøge at belyse ved at fortælle om de vigtigste tilbageføringer af kulturgods mellem Danmark og Tyskland siden 1864.

\section{ÆLDRE TIDERS KRIGSEROBRINGER}

En af de første markante overføringer af kulturgods til Danmark var den gottorpske hertugs kunstkammer, hvis glansstykker blev ført til det kongelige kunstkammer i København i midten af 1700-årene. Den gottorpske hertug havde under Den Store Nordiske Krig været allieret med svenskerne mod den danske konge og lidt et klart nederlag. Derfor var den gottorpske statsdannelse blevet opløst i 1720 og de gottorpske områder inkorporeret i det danske monarki. Det er ikke blot tale om territoriale indlemmelser, også gottorpernes kulturgods blev inkorporeret. Det imponerende kunstkammer, der skulle vise hertugernes repræsentative formåen og kulturelle niveau blev i 1750 indlemmet i Det Kongelige Kunstkammer i København. ${ }^{1}$ Der var ingen bortset fra den hertugelige familie, der kunne have noget mod dette, da genstand- 
ene i de europæiske kunstkamre udelukkende havde imageskabende formål for fyrsterne. Der var endnu ingen forestillinger om, at der fandtes særegent nationalt kulturgods, for befolkningerne blev endnu kun betragtet som fyrsternes undersåtter, ikke som nationer med selvstændige rettigheder.

Dette forhold ændredes drastisk efter den franske revolution, hvor forestillingen om "folket" som statens grundlag og statsmagtens legitimerende faktor blev udbredt. I løbet af 1800-tallet blev hovedparten af de gamle sammensatte fyrstestater afløst af nationalstater, og ofte skete dette ved, at områder blev udskilt. Jævnsides hermed blev der udviklet den tanke, at der fandtes en fælles kulturarv, som tilhørte en hel nation, og at en enkelt person ikke havde lov til at bemægtige sig kulturarven alene. De fyrstelige kunstkamre blev opløst, og indholdet spredt ud på alment tilgængelige museer. Allerede i 1806 blev ordet "Nationalmuseum" første gang anvendt på dansk i et forslag til omdannnelse af det kongelige kunstkammer, som blev spredt ud på flere nydannede museer. ${ }^{2}$ De gottorpske genstande drømte ingen om at tilbageføre til Gottorp. De var blevet til en del af dansk kulturarv, idet hele Slesvig var blevet inkorporeret i Det Danske Rige.

Under Napoleonskrigene var Danmark på den tabende parts side, idet Frederik 6. stod ved sit kongelige løfte og holdt med Napoleon til den bitre ende. Denne trofasthed kom til at koste dyrt for det danske-norske dobbeltmonarki. Sverige havde klogeligt skiftet side under krigen og dermed placeret sig blandt sejrherrerne, hvor også Rusland befandt sig. Zaren havde allerede i 1809 sikret sig herredømmet over Finland, og Sverige krævede nu herredømmet over Norge. Som tabende part var der stort set ikke andet at gøre for den danske konge end at acceptere kravet. Det blev ikke efterfulgt af svensk krav om udlevering af norsk kulturgods i dansk eje. De omfattende overførsler af arkivalier fra det danske til det norske rigsarkiv er først sket langt senere. Det eneste svenske krav vedrørende kulturarv i forbindelsen med overtagelsen af Norge var fjernelsen af Norske Løve fra det danske kongelige våben. Dette krav blev opfyldt med et nyt kongevåben i 1819 . Igen et udtryk for forestillingen om, at staten og fyrsten var synonymer.

På europæisk plan skete der et par markante tilbageførsler af kulturgods efter Napoleons ran under de franske erobringskrige. Firspandet på Brandenburger Tor i Berlin kom atter på plads efter nogle år i Paris, og det samme gjaldt San Marco-løverne i Venezia, der også var fjernet efter ordre fra den franske kejser. Hermed var lagt en spire til senere tiders forestillinger om, at der findes noget umisteligt kulturgods, som ikke blot kan flyttes omkring efter sejrherrers skøn.

Første SLESVIGSKe KRIG I848-I850

I 1848 var Danmark på ny i krig; denne gang var det en borgerkrig inden for monarkiets grænser. Gnisten fra de europæiske revolutioner slog ned både i København og Kiel. I København stillede det nationalliberale borgerskab krav om en fælles fri forfatning for kongeriget og Slesvig, og i Kiel ønskede det nationalliberale borgerskab en fælles fri forfatning for Slesvig og Holsten. Kravene var trods stor politisk lighed - umulige at forene, da det samme territorium indgik i dem begge. Resultatet blev en borgerkrig, der kom til at vare tre år. I foråret 1848 blev der proklameret en selvstændig slesvig-holstensk stat, der hurtigt blev forsynet eget nationalflag, 
24 landsvåben, forfatning, regering, lovgivende forsamling, penge og frimærker. Men efter tre års krig mod Danmark var pengekassen tom, og de tyske fyrster følte ingen trang til at støtte en liberal regering i Slesvig-Holsten. Derfor blev den nye statsdannelse nedlagt i 1851, og det danske monarki genetableret i sin fulde udstrækning med støtte fra de europæiske stormagter.

I sagens natur foregik der ingen tilbageføring af kulturgods efter borgerkrigen, da der var tale om en genetablering af den danske fyrstestat. Derimod blev der fjernet slesvigholstensk kulturgods, især den nyskabte nationalsymbolik. Først og fremmest det blåhvide-røde nationalflag, det slesvig-holstenske våben og en række nyplantede dobbeltege, der var symbol på den kulturelle samhørighed mellem Slesvig-Holsten og det tyske folk. Flag og nationalsang blev forbudt, og dobbeltegene blev fældet. Men selvom materiel kulturarv kunne tilintetgøres, forsvandt den kulturelle identitet hos borgerne ikke. Under borgerkrigen havde der været udkæmpet en række slag, og der var derfor krigergrave i Slesvig fra begge krigens parter. Disse grave fik lov at ligge uberørte, men flagning med den slesvig-holstenske trikolore ved gravene var strengt forbudt.

I 1862 blev der på kirkegården i Flensborg, hovedbyen i Slesvig, rejst et stort mindesmærke, Istedløven. ${ }^{3}$ Det blev opsat på initiativ af den fremtrædende nationalliberale politiker Orla Lehmann og forestillede en løve, våbendyret i det danske rigsvåben. Billedhuggeren H.V. Bissen havde gengivet løven som et majestætisk udseende dyr, der sad på spring på en høj sokkel. Den fremstod som indbegrebet af styrke, årvågenhed og sejrsvilje. For danskere var monumentet et gravminde over de mere end 400 danske soldater begravet på

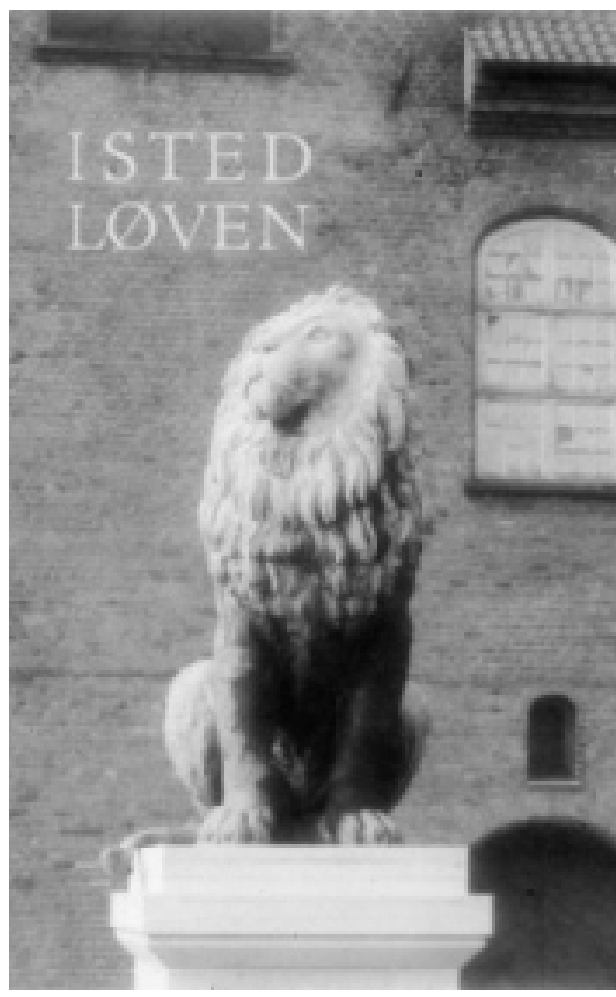

Den slesvigske billedhugger H.V. Bissens statue med Istedløven står her ved Tøjhusmuseet $i$ København på Soren Kierkegaards Plads. Intet andet dansk mindesmarke har varet så omstridt.

kirkegården i Flensborg, mens det for slesvigholstenerne var et sejrsmonument med en helt upassende placering på en kirkegård med talrige krigergrave fra begge parter i borgerkrigen. ${ }^{4}$

Værst var det dog for slesvig-holstenerne, at der var fjernet noget af deres nyere kulturarv ved opsætningen af det danske mindesmærke. Der var sløjfet slesvig-holstenske krigergrave fra den første slesvigske krig. Hvis dette var sket 100 år tidligere, ville gravsløjfninger næppe have udløst kritik, for solda- 
terne var dengang gemene lejetropper, der kæmpede for en sold ydet af skiftende fyrster. Oprettelsen af nationale hære baseret på almindelig værnepligt medførte imidlertid, at soldaterne blev betragtet som landsmænd, der skulle stride og om nødvendigt falde i kampen for det fælles fædreland. Derfor virkede fjernelsen af de slesvig-holstenske grave til fordel for opsætning af et dansk mindesmærke så ophidsende.

I Flensborg blev der i 1852 etableret et provinsmuseum, det andet inden for det danske monarki. Det omfattede talrige oldsager fra hertugdømmet Slesvig, især fund fra store udgravninger i de slesvigske moser, Thorsbjerg og Nydam. I Nydam i Nordslesvig var der i 1861 blevet fundet en stor båd, der blev samlet og udstillet lige før udbruddet af Anden Slesvigske Krig. Museet i Flensborg fik efter datiden en meget stor økonomisk støtte, fordi forhistorisk arkæologi havde fået status som dansk nationalvidenskab på grund af de dansk-tyske stridigheder om den slesvigske nationalitet.

\section{Anden SLesvigske KRIG I864}

I februar 1864 udbrød Anden Slesvigske Krig, der denne gang foregik med Danmark på den ene side, og Preussen og Østrig på den anden side. Så snart de tyske styrker havde indtaget Flensborg, gik slesvig-holstenske patrioter i gang med at nedtage den store løve. Ganske vist protesterede både den preussiske ministerpræsident Bismarck og den preussiske general Wrangel, men uden resultat. Symbolet på det danske overherredømme skulle væk, og der var slesvig-holstenske patrioter nok i Flensborg til at sørge for det. Løven blev indtil videre lagt på lager i rådhuset i Flensborg.

Også et andet markant nyrejst dansk min- desmærke var udsat for hærværk. Det var en mindestøtte over kampen for bevarelse af det danske sprog i Slesvig, der var rejst på Skamlingsbanken, et højdedrag i det nordligste Slesvig. Her var der fra 1843 blevet afholdt store friluftsmøder, og stedet havde været nationalt samlingssted. I efteråret 1863 var der blevet opsat en mindestøtte af kvadre af svensk granit med navne på fremtrædende danske og dansksindede slesvigere, der havde talt imod den sproglige fortyskning af Slesvig. Det var den civile, ubevæbnede kamp for landsdelen, som blev afspejlet i dette mindesmærke, men det vakte alligevel tysk harme, og det blev bombesprængt i foråret 1864 . Granitkvadrene blev bortsolgt på auktion kort tid efter, og herved var tilsyneladende sket en udradering af kulturarven. Men de mange sten fra mindestøtten blev købt af to dansksindede bønder og lagt i hegnene ved deres marker. Ved fredsslutningen i efteråret 1864 kom de otte nordligste sogne i Slesvig med til Danmark, og Skamlingsbanken kom herved til at ligge i Danmark. Granitkvadrene blev nu skænket til genetablering af mindesmærket, og to år efter krigen, i 1866, blev Skamlingsbankestøtten genrejst. Med sine talrige skår og ar på stenene fremtrådte den ikke blot et minde over den danske sprogkamp i Slesvig, men også som et vidnesbyrd om tysk hærværk mod dansk kulturarv.

I 1867 blev Istedløven bragt fra Flensborg til Berlin og opstillet som krigstrofæ i den indre gård til Zeughaus-Museum, der lå på Unter den Linden. Her stod den i 10 år, men var alt for stor i proportionerne til den indre gård, hvor den var anbragt. Derfor blev den i 1877overført til et militærakademi i Lichterfelde lidt uden for Berlin. Her stod den gennem næsten 70 år som et mindemærke fra den første af de tre krige, der førte til Tysk- 
26 lands samling. I Danmark var Istedløvens fjernelse og dens senere flytning til Berlin et bevis på sejrherrernes uædle dåd, og Istedløven fik ligesom den skrammede Skamlingsbankestøtte en skær af martyrium over sig. Begge mindesmærker blev lavet i miniudgaver og indgik i udsmykningen af hjemmene hos nationaltsindede borgere og fandtes tillige på de fleste danske folkehøjskoler. Istedløven og Skamlingsbankestøtten blev på denne vis fastholdt i den folkelige bevidsthed som en vigtig del af den danske kulturarv. I den nationale identitet indgår der altid en forestilling om "de andre", og denne forestilling var meget klar i kopierne af de to mindesmærker, der begge havde været udsat for tysk hærværk.

Også et andet 1864-krigstrofæ blev ført fra Slesvig til Berlin. Det var en runesten fra vikingetiden med den korte indskrift "Hærulf", antageligt et mandsnavn. Runestenen var blevet erhvervet af kong Frederik 7 . allerede i 1854 og anbragt ved hærvejen i Slesvig. Her blev stenen opdaget af den historisk interesserede preussiske prins og general, Friedrich Carl, der var aktiv i den tyske overkommando under 1864-krigen. Han fik runestenen sendt til sit jagtslot "Dreilinden" nær Potsdam. Slottet var efter den preussiske sejr på Dybbøl blevet omdøbt til "Düppel-Dreilinden", og runestenen blev anbragt ved foden af de tre lindetræer som et mindesmærke over prinsens indsats ved erobringen af Dybbøl Skanser - det man fra tysk side betegnede som Slesvigs befrielse. Stenens indskrift blev i samtiden tolket som et navn af dansk rod, der viste, at hertugdømmet Slesvig fra oldtiden havde været beboet af dansktalende folkeslag. Dette bekymrede dog ikke prinsen, men i Danmark blev den danske runesten ved Potsdam ikke glemt. ${ }^{5}$
I fredsslutningen i 1864 kom der en bemærkelsesværdig paragraf om kulturarv, vel nok en af de første gange, hvor dette er medtaget i en mellemstatslig aftale. Den drejede sig om Flensborgsamlingen. ${ }^{6}$ Dette betydelige museum var blevet pakket sammen og sendt bort ved krigens udbrud. Tilbage i Flensborg var den store Nydambåd og nogle få andre genstande. Den øvrige del af samlingen og dens protokoller var sendt nordpå, hvor sporene forsvandt. Hvor den var havnet, vidste ingen, tilsyneladende heller ikke den ansvarlige for samlingen. Preussen og Østrig var meget utilfredse, da kulturgods af denne art var prestigeskabende for et område, og for første gang blev proveniensprincippet for kulturgods påberåbt i en international aftale. Et krav om den danske regerings medvirken i eftersøgningen og accept af tilbageføringen var en del af fredsaftalen. Takket være et tilsagn om en stor dusør fra den preussiske regering blev samlingen bragt til veje i 1867 og udleveret. Det skete med de danske arkæologers dybe uvilje, og samlingens originalprotokoller kom først til veje et halvt århundrede senere! Arkæologerne i København følte, at det var dansk hjerteblod, der her fik lov at løbe - til trods for, at samlingens hovedtyngde lå i jernalderen, århundreder før skabelsen af det danske rige.

\section{DANSKE UDLEVERINGS $\varnothing$ NSKER} EFTER Slesvigs DELiNG I I920

Tyskland var blandt taberne i verdenskrigen $\mathrm{i}$ 1918, og som følge heraf blev der i 1920 afholdt folkeafstemning om Slesvigs fremtidige statslige tilhørsforhold. I den nordlige del stemte $75 \%$ for Danmark, og i den mellemste del stemte $80 \%$ for Tyskland. I henhold til folkeafstemningen blev området nu delt, og 
en ny dansk-tysk grænse blev trukket tværs gennem Slesvig.

Allerede i januar 1919, mere end et år før folkeafstemningen i Slesvig, havde de to direktører for Nationalmuseet i København henvendt sig til den danske regering og anmodet om, at der blev rejst krav om tilbageføring af Flensborgsamlingen, der befandt sig på museet i Kiel. De understregede, at det lå den danske offentlighed stærkt på sinde at få denne samling, og der blev udarbejdet et memorandum om tilbageføring af omkring 100 danske kulturværdier fra Tyskland. ${ }^{7}$ Foruden Flensborgsamlingen var der tale om genstande af særlig kunstnerisk eller litterær art. Som begrundelse anførtes det proveniensprincip, som man fra tysk side selv havde anvendt i 1864. Blandt de ønskede genstande var også Istedløven, selvom det var højst usikkert i 1919, om Flensborg ville få dansk flertal og komme med til Danmark. Man begrundede ønsket med, at løven havde en dyrebar plads i danske hjerter og henviste i øvrigt til tilbageføring af San Marco-løverne og firspandet på Brandenburger Tor.

I Versailles-traktaten fra 1919 kom der imidlertid ingen generelle aftaler om udlevering om kulturgods. Der var kun nævnt nogle få krigstrofæer, kunstværker og kuriositeter, som skulle tilbageføres, og valget af disse ting synes ikke at vidne om nogen forståelse for begrebet kulturarv. Blandt andet skulle den britiske regering have udleveret sultan Yakaouas pandeskal! De danske ønsker om tilbageføring måtte derfor tages op i en mellemstatslig aftale mellem Danmark og Weimarrepublikken efter Slesvigs deling i 1920 .

Det blev kamp til stregen, og den danske regerings forsøg på en bytteaftale blev konstant afvist fra tysk side. I det nu danske Nordslesvig var der to store tyske sejrsmonu- menter fra 1864-krigen på Dybbøl og Arnkil nær Sønderborg. Dem tilbød den danske regering at nedtage og udlevere til Tyskland mod at få udleveret Istedløven fra Berlin. Begge parter skulle så garantere, at ingen af disse mindesmærker blev genopstillet i Slesvig. Dette forslag blev straks afvist fra tysk side, og man understregede Danmarks forpligtelse til at passe og vedligeholde de tyske mindesmærker på dansk grund. Heller ikke Flensborgsamlingen var der mulighed for at få tilbageført, da den omfattede genstande både fra (det danske) Nordslesvig og (det tyske) Sydslesvig. Derimod blev Städtisches Museum, bymuseet, i Flensborg omfattet af aftalerne om tilbageføring af kulturgods. Byen havde et stort tysk flertal og forblev under tysk styre, men lå kun et par kilometer syd for den nye grænse. For bymuseet medførte Slesvigs deling, at alt nordslesvigsk kirkeinventar, som museet ikke havde købskvitteringer på, skulle udleveres til Danmark. På Städtisches Museum var direktøren modstander af den mellemstatslige aftale og gik endda så vidt i sin demonstration af sin uvilje, at han i en årrække bibeholdt de tomme pladser i udstillingen og lod opsætte skilte med den lakoniske tekst: "Zufolge des Versaillesvertrag an Dänemark ausgeliefert". ${ }^{8}$

Næsten lige så svært var det med udveksling af arkivalier. Denne sag kom til at strække sig over tre rigsarkivarers tid såvel på dansk som på tysk side, og først i 1937 begyndte lastbilerne at rulle mellem det slesvig-holstenske landsarkiv og det danske rigsarkiv. I alt blev der afgivet 12 tons arkivalier fra dansk side. ${ }^{9}$ Denne udveksling havde dog kun interesse blandt fagfolk og ikke i offentligheden, da arkivalierne ikke havde samme identitetsskabende betydning som genstande og mindesmærker. 
Ved det tyske sammenbrud i 1945 blev Berlin erobret af russerne og delt mellem de fire allierede parter. Franskmændene øvede straks selvtægt overfor Siegessäule, et sejrsmonument over de tre krige, der førte til Tysklands samling. Reliefferne på søjlens fundament blev ført til Paris. Værre gik det med Zeughausmuseum, der helt blev opløst med de fire besættelsesmagters velsignelse. Russerne tog rigeligt for sig af retterne i museerne i sin del af den tyske hovedstad, og de vestallierede besættelsesmagter gjorde det samme i noget mindre målestok. En dansk korrespondent, Henrik Ringsted fra dagbladet Politiken, overværede en amerikansk parade ved militærakademiet i Lichterfelde og så her Istedløven i landflygtighed. Han gjorde opmærksom på sagen over for den amerikanske øverstkommenderende i Berlin, som henvendte sig i september til general Eisenhower med forslag om løvens tilbagelevering. Denne krævede imidlertid, at der kom en skriftlig anmodning herom fra den danske regering. En amerikansk oberst rejste til København og fik fra udenrigsminister Christmas Møller en note, der lød således: "Jeg kan ikke forestille mig noget, der ville gøre det amerikanske folk mere populært hos danskerne end genindsættelsen af Istedløven på dens rette plads i Danmark. Sagen bør fremmes mest muligt." 10

Ønsket fra den danske regering blev imødekommet, og den 5. oktober ankom en amerikansk blokvogn til København med den store bronzeløve på ladet. Den blev læsset af ved Tøjhusmuseet, og ved en stor festlighed et par dage senere blev Istedløven overdraget til kong Christian 10. af den amerikanske general Ray W. Barker. Kongen takkede og udtrykte ønske

om, at den "naar Forholdene tillader det" kunne opstilles nede i Flensborg til erindring om alle dem, der havde ofret deres liv i Treårskrigen.

Løven blev opstillet på en midlertidig sokkel et midlertidigt sted, og siden 1945 har der ikke været ét år uden debat om løvens endelige opstilling. Debatten foregår både i Danmark og i Slesvig-Holsten, og der er tydelige politiske tendenser i debatten. De tyske SPD'ere vil tillade tilbageføring af det danske kulturminde, mens CDU'ere betakker sig. I Danmark er det især folk af nationalkonservativ observans, der går ind for tilbageføring til kirkegården i Flensborg eller til et mere markant sted i Danmark. Men der er næppe tvivl om, at løven vil forblive i København på det "midlertidige" sted. Den "midlertidige" sokkel er for et par år siden blevet forbedret uden dog at få en "endelig" karakter. Spørgsmålet om Istedløvens endelige placering er ikke en sag, der kan engagere andre end en meget lille kreds. Den er blevet til dødt kulturgods, der ikke længere er styrkende for dansk identitet. Det hænger sammen med, at det dansk-tyske forhold har ændret sig markant siden det tyske nederlag i Anden Verdenskrig, og at Tyskland ikke på samme vis som tidligere kan opfattes som en reel trussel mod dansk selvstændighed.

\section{DANSK HÆRVÆRK \\ MOD TYSK KULTURARV I I945}

Efter de fem års tysk besættelse foregik der i 1945 et juridisk retsopgør i Danmark, men der udspillede sig også et mere folkeligt opgør i form af en veritabel billedstorm mod mange tyske kulturminder i Nordslesvig. De to store sejrsmindesmærker fra 1864 på Dybbøl og Arnkil blev lagt i ruiner, og et stort 
Bismarcktårn på Knivsbjerg ligeledes. Desuden blev talrige små tyske mindesmærker over hele landsdelen ødelagte. De fleste tyske kulturlevn fra de 56 år under tysk styre forsvandt herved for stedse. Kulturlandskabet i den del af Slesvig, der var blevet dansk i 1920 mistede herved et del af sit karakteristiske præg, men dette blev ikke beklaget fra dansk side, hverken af historikere eller i den brede offentlighed. Der var en udbredt enighed om, at de tyske kulturlevn havde været skæmmende rent æstetisk! Kejsertidens nygotik blev bedømt som en "udansk" stilart.

I Museet på Sønderborg har vi forskellige rester af disse mindesmærker, og enkelte vil kunne genetableres, men ingen - heller ikke medlemmer fra det tyske mindretal - udtrykker ønsker herom. Det skyldes, at det er kulturlevn fra et kejserrige, som de færreste medlemmer af det tyske mindretal kan identificere sig med i dag. Den nutidige tyske forbundsrepublik er ikke en videreførsel af det tyske kejserrige, men er på afgørende punkter forskellig herfra.

\section{TYSK TILBAgEFØRSEL PÅ FRIVILLIG BASIS SIDEN ANDEN VERDENSKRIG}

Nogle få af de genstande, der blev nævnt i det danske memorandum i 1919 er blevet tilbageført som en særlig tysk gestus. Det drejer sig om Hærulfstenen, som det berlinske senat på initiativ af overborgmester Ernst Reuter i 1951 besluttede at lade tilbageføre fra det prinselige jagtslot Dreilinden til Nordslesvig, hvor runestenen blev genopstillet ved Hærvejen. ${ }^{11}$

Også en anden runesten, Ketil Urne-stenen, er blevet tilbagegivet. Den var i 1841 overdraget af menigheden i Bjolderup til det nyoprettede "Museum der vorgeschichtlichen
Alterthümer” i Kiel, det første uden for København i den dansk-tyske helstat. Sognebørnene i Bjolderup ville sikre den værdifulde gravsten med runeindskrift for eftertiden. Det havde museet varetaget, selvom det havde haft en omskriftelig tilværelse både på det ydre plan med ny statsoverhøjhed og på det indre plan med rømninger under krige og flere flytninger. Tilbageføringen skete i anledning af det slesvigholstenske museumsvæsens 150 års dag og var motiveret med, at initiativet til museet var kommet fra dansk side. Tilbageføringen skulle understrege det gode forhold mellem dansk og tysk museumsvæsen i almindelighed og på det arkæologiske område $\mathrm{i}$ særdeleshed, og kulturministre og museumsdirektører fra begge lande var til stede og holdt taler. ${ }^{12}$ Heri blev det understreget, at nationaltsindede borgere ikke skulle begynde at skrive ønskesedler om flere tilbageføringer af kulturgods. Fra dansk side blev det understreget, at der findes talrige genstande fra det nuværende Slesvig-Holsten i dansk besiddelse, og at det ikke tjente danske interesser at fjerne alle spor af den tid, hvor det danske monarki havde en helt andet territorial udstrækning end i dag.

\section{GENSIDIGE DANSK-TYSKE DEPONERINGER I I995}

Trods denne kontante afvisning af flere tilbageføringer var der i Kværs sogn i Nordslesvig en drøm om at generhverve en værdifuld genstand. I midten af 1800-tallet havde sogneboere kasseret den middelalderlige døbefont og anskaffet en nygotisk font i kunststen. Den romanske font endte som drikketrug for heste på gården Tvingholm. Her blev den opdaget af museumsfolk fra Flensborg i 1902 og straks erhvervet formedelst 200 Mark. På 
30 museet blev den udstillet sammen med kirkeinventar fra Nordslesvig, hvoraf det meste var deponeret fra kirkerne.

Da Kværs-fonten var købt af museet i Flensborg - og ikke deponeret - blev den ikke tilbageført i 1920. Dette var beboerne i Kværs kede af, og siden 1950erne har der været talrige henvendelser til Sønderborg Slot om bistand til at få tilbageført dette kulturgods. Her afviste museumsinspektørerne at medvirke, da bymuseet havde erhvervet døbefonten på regulær vis og herved sandsynligvis reddet den fra at gå helt til - ingen kunne anfægte dette. Alligevel kom kværsborgernes gamle ønske til at gå i opfyldelse i 1995, og det skyldtes, at det indgik i en større aftale mellem museerne i Flensborg og Sønderborg, byggende på gensidighed og tillid. Kværs-fonten tilhører fortsat Städtisches Museum, der har deponeret den på Sønderborg Slot, der med tilladelse fra ejeren har videredeponeret den til kirken i Kværs. Juridisk er der tale om et langtidsudlån fra Flensborg, en såkaldt Dauer-Leihgabe, og det museale ansvar for fonten ligger i Sønderborg. Der er dog tale om rent formelle detaljer, og døbefonten blev da også ført direkte fra bymuseet i Flensborg til sognekirken i Kværs. ${ }^{13}$

Deponeringen af Kværs-fonten indgår i en udveksling af genstande, der skal tjene til at styrke det regionale særpræg ved museerne i Sønderborg og Flensborg. Aftalen om udveksling af museumsgenstande er truffet i sommeren 1995, og den er et resultat af et mangeårigt, godt samarbejde mellem de to museer på hver side af den dansk-tyske grænse. I de seneste år er dette samarbejde blevet styrket, hvad den nye aftale er vidnesbyrd om. For begge museers vedkommende er det i overvejende grad tale om genstande, der har været i magasin og nu kan indgå i bedre kultur- historiske sammenhænge hos nabomuseet. Städtisches Museum har fra Sønderborg Slot bl.a. fået deponeret træskærerarbejder fra det sydvestlige Slesvig. For blot 10-15 år siden ville det ikke have været muligt at indgå aftaler af denne art, men siden da har det grænseoverskridende samarbejde udviklet sig fra skåltale-retorik til konkret samarbejde.

\section{HVAd ER UMistelig KULTURARV}

Hvorfor bliver nogle ting til kulturarv og andre ikke? Dette spørgsmål kan bedst besvares ved at se på jernalderbåden fra mosen i Nydam. Den făr sin identitetskabende betydning af tre årsager: På grund af striden om hertugdømmet Slesvig blev dansk arkæologi fra sin grundlæggelse til en nationalpolitisk videnskab, og arkæologer leverede videnskabelige belæg til politikernes argumenter. Båden blev fundet i den nordlige del af Slesvig, hvor flertallet af befolkningen altid har været dansktalende, og hvor der fra midten af 1800-tallet blev udviklet en dansk identitetsfølelse nært knyttet til historien. Endelig blev båden udgravet kort tid før udbruddet af den anden slesvigske krig i 1864, og efter krigsnederlaget blev det museum, hvori den var indgået opløst, og båden kom til museet i Kiel.

Hærulfstenen er også blevet betegnet som umistelig dansk kulturarv, selvom den slet ikke indeholder en indskrift, der fortæller om dansk historie på samme vis som de to runesten ved Jelling eller runestenene ved Danevirke gør. Men i kraft af at være vidnesbyrd om gammel dansk bosættelse i Slesvig bliver stenen til et bevis på danskernes førstefødselsret til dette område. Ganske vist blev Slesvig i 1920 delt efter princippet om den nulevende befolknings selvbestemmelsesret, men forestilllingen om historiens ret har de fleste haft 
svært ved at lægge bag sig. Afstamning var for mange et vægtigere argument end afstemning! Forestillingen om (etnisk) kontinuitet giver (politisk) legitimitet.

Endelig er der Istedløven, hvis placering endnu kan vække ophidselse i meget små kredse. At den blev til nationalt kulturgods, hænger nært sammen med dens dobbelte funktion som sejrsminde og gravmæle. Den er faktisk et af de meget fà danske sejrsmindesmærker. Siden Store Nordiske Krig i begyndelsen af 1700-årene har Danmark stort set tabt de krige, landet har medvirket i. De to eneste slag, hvor der har været dansk sejr, foregik ved Fredericia i 1849 og ved Isted i 1850. Det er derfor heller ikke tilfældigt, at der er dannet en forening til nyopstilling af Istedløven på volden i Fredericia. Begrundelsen er ganske vist af kunstnerisk art - i denne by er der andre kunstværker af H.V. Bissen, billedhuggeren, der også har skabt Istedløven. Men det er næppe kunsttrang, der kan fă folk til i årevis at arbejde for en sag af denne art. Når Istedløven kan vække stærke følelser i nogle danskere, skyldes det, at den afspejler forestillinger om fordums storhed og vilje til at forsvare territoriet. Hermed er vi nået ind til benet: Umistelig kulturarv, som ønskes tilbageført til en nation, skal rumme en fortælling, som alle har lyst til at høre om - helst en historie om nationens storhed og viljestyrke.

\section{Noter}

1. Mette Skougaard (red.): Gottorp - et fyrstehof $i$ 1600-tallet. København 2002.

2. Rasmus Nyerup: Oversyn over Fadrenelandets Mindesmarker fra Oldtiden, saaledes som samme kan tankes opstillede i et tilkommende National-
Museum. Historisk-statistisk Skildring af Tilstanden $i$ Danmark i aldre og nyere Tid. Bd. 4. København 1806.

3. Bjørn Poulsen og Ulrich Schulte-Wülwer (red.): Istedløven. Et nationalt monument og dets skabne. Herning 1993.

4. Inge Adriansen: Istedløven - et nationalt monument med vekslende symbolindhold. I: Poulsen og Schulte-Wülwer 1993, s. 81-116.

5. Stine Wiell: Løven, stenen og båden. Kulturminder i nationalpolitisk spil. I: Poulsen og Schulte-Wülwer 1993, s. 117-138.

6. Stine Wiell: Flensborgsamlingen 1852-1864-og dens skabne. Flensborg 1997.

7. Memorandum vedrorende Tilbagelevering fra Tyskland (Preussen) af Kunstgenstande eller genstande af videnskabelig, litterer eller historisk Vardi som Folge af Tilbagegivelsen af den danske Del af Slesvig. Folketingets Bibliotek, Christiansborg. Udateret. [1919]

8. Barfod, Jørn: Eine Episode aus der Geschichte des Flensburger Museums. I: Die Heimat 1982, s. 368 .

9. Hans H. Worsøe: Den arkivalske grænse. I: Henrik Becker Christensen (red.): Grensen $i 75$ år. Aabenraa 1995, s. 268-296.

10. Barney Oldfield: Da Istedløven kom tilbage. Kronik i dagbladet Politiken 25.juli 1962.

11. Stine Wiell 1993 s. $131 \mathrm{f}$.

12. Inge Adriansen: Ketil Urne - en runesten vender tilbage. I: Sønderjysk Månedsskrift 1987, s. 254256.

13. Inge Adriansen: Kværs-døbefonten vender tilbage. I: Sønderjysk Månedsskrift 1995, s. 215 - 220.

Museumsinspektør Inge Adriansen

Adr. Museet på Sonderborg Slot, DK-6400 Sønderborg Fax: +4574422492

E-mail:ia@sonderborgslot.dk 